(374) 高N含有オーステナイト系ステンレス鋼の高温引張延性

日新製金烊(株)周南製鎡所植松美博星野和夫

1. 緒 言：高N含有r系ステンレス鋼は，室温では優れた強度と延性を示すが，高温では特定の 温度籍囲で延性が著しく低下寸る現象え示ず。この種の脆性は銅および铜合金で中间温度脆性として検 討されているが，光の機棤については不明な点も多い。本報告はType 304 Nの高温引張延性に及作要 因を調査し，本鋼の延性低下現象について検討したものである。

2. 实験方法：供試材の化学組成を表1に示す。試料は，实験室的に溶製した小鋼塊を镀造により

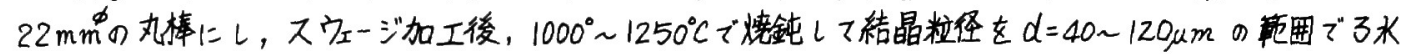
染に調整したものを用いた。丁人法による高温引張

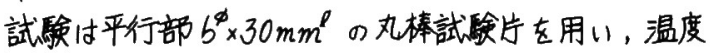

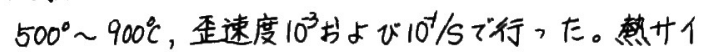

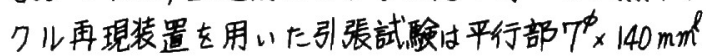
の丸棒試験片女用い，因1下示才丁，K2種類の热

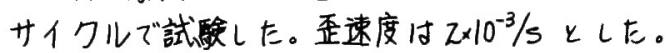
表 1. 供試材の化学組成 (Wt\%)

\begin{tabular}{|c|c|c|c|c|c|c|c|c|c|c|}
\hline \multicolumn{2}{|c|}{ 铜種成分 } & C & Si & $\mathrm{Mn}$ & $\mathrm{P}$ & $\mathrm{S}$ & $\mathrm{NI}$ & $\mathrm{Cr}$ & $\mathrm{N}$ & $\mathrm{CP}_{\mathrm{CP} \mathrm{P})}$ \\
\hline \multirow{2}{*}{304} & S1 & 0,06 & 0.6 & 1.15 & 036 & 010 & 11,8 & 18.8 & 0.01 & 72 \\
\hline & S2 & 0.06 & 0.6 & 1.18 & .027 & .008 & 12.1 & 18.1 & 0.03 & 100 \\
\hline \multirow{2}{*}{$304 \mathrm{~N}$} & N1 & 0.01 & 0.6 & 1.24 & .034 & .005 & 11.8 & 17.8 & 0.13 & 60 \\
\hline & N2 & 0.05 & 0.6 & 1.22 & 024 & .008 & 12.1 & 18.3 & 0.12 & 90 \\
\hline
\end{tabular}

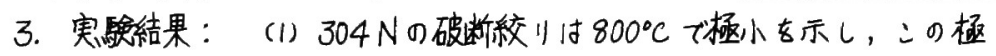

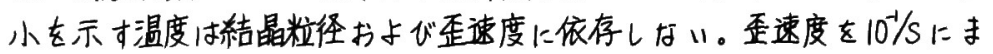

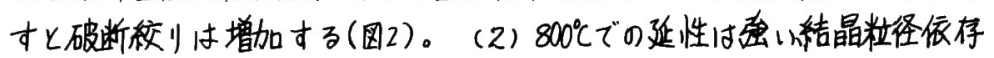
性を示す(图了)。各粗径に対する絞川值は304 と 304 N で約25\%の差がある

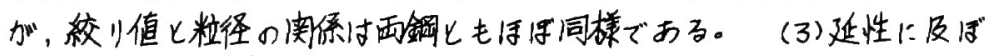
才加㷫形状の影管女調べた結果，304は热势イクル丁では延性低下を示 すが, 熱サイクルKでは延性低下を示さない。一方，304Nは熱开イク ルKでも延性低下を示し、この極小七なる温度は750Cに移行し，かつ 延性低下を示才温度巾は减少している(图4)。（4）S1およびN1の引镸後 の破面镜察から，延性低下を示榅度域では，絞值と粒界破面率讨対

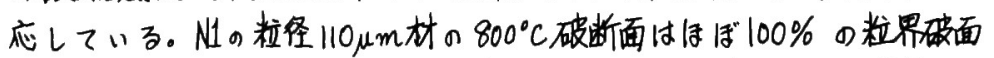
率を示している(写真1)。粒界破填については，粒界すべリの観察女行

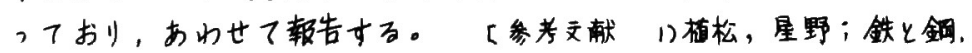

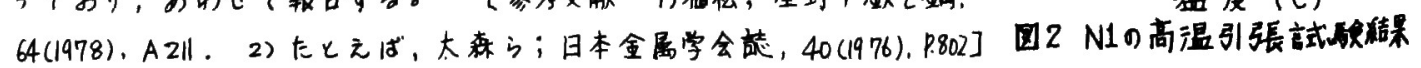

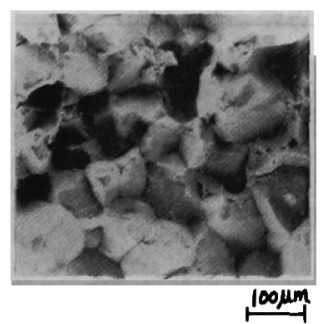

写真1. $N 1(d=110 \mu \mathrm{m})$ 材の $800^{\circ} \mathrm{C}$, $10^{-3} / \mathrm{s}$ 引張破断缕 の破 西観察結果

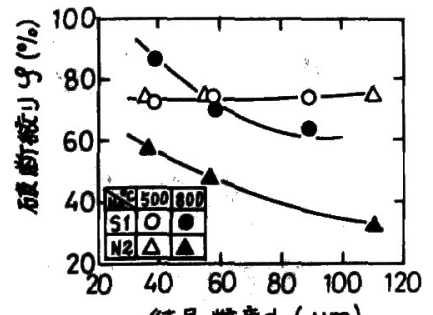

結昆粗度 $(\mu \mathrm{m})$

四了. 破断紋りに及ぼす結晶粒 径の影䈏

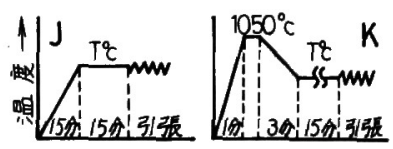

因1 整开㣙形状

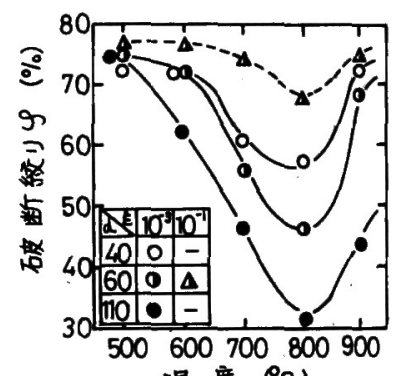

温度 ( $\mathrm{C}$ )

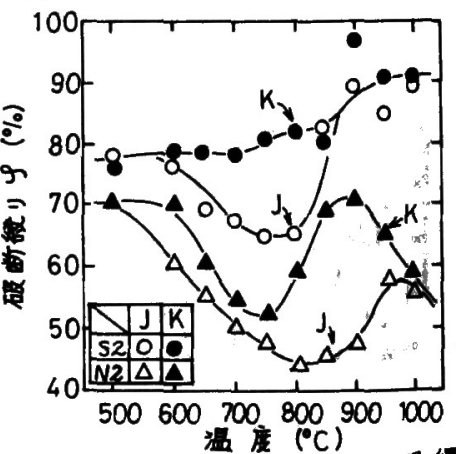

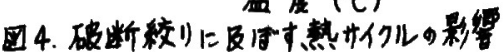


669 . ; .018.8:621.771.23.016.3:621.785.371:669.781:539.434:620.186

(375) 高速炬燃料被覆管用 $\gamma^{\prime}$ 析出強化型高N $\mathrm{i}$ ステンレス鋼冷間加工材の高温特性

$$
\text { 神製鋼中央研究所太田定雄藤原優行 }
$$

○内田博幸

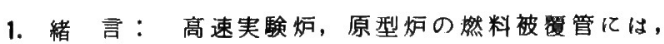
冷間加工施した 18-8 Mo鋼が用いられるが, 実用 炣ではさらにクリープ強度と耐スウェリング性の優れ た材料が要求される。筆者らは，とれまで主に炭化物 析出強化型の冷間加工材について検討し， Bを微量添 加した $15 \mathrm{Cr}-30 \mathrm{Ni}-\mathrm{Mo}-\mathrm{T}$ i 鋼少優れた特性を有 するととを明らかにした。炭化物以外に $r^{\prime}$ 相の析出が 强度、スウェリングの改善に有効とされているが, 被 覆管のように冷間加工を施した $r^{\prime}$ 析出强化型合金のク リープ強度について調べた研究ははとんどない。そと で, 本研究では, $\gamma^{\prime}$ 析出強化型の $14 \mathrm{Cr}-35 \mathrm{Ni}-\mathrm{Mo}_{\mathrm{O}}$ 鎆、命間加工材のクリープ強度に及ぼすBおよび溶体 化処理温度の影響を検討し，またクリープ中の組織変 化を調べた。

2. 方法：供試材の化学成分表 1 に示す。真空

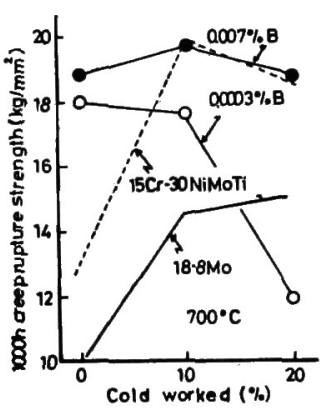

図1. 冷間加工事の影㢸

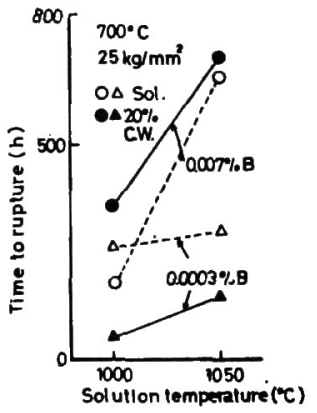

因 2. 容体化処理温度の叞罄

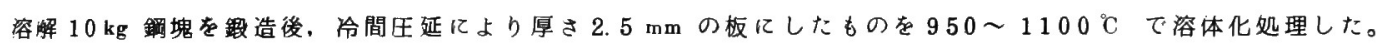
とれを容体化処理材とし，さらに 10，20\%冷間加工を施したものを試験材とし，700 C で，クリープ破断 試験を行った。

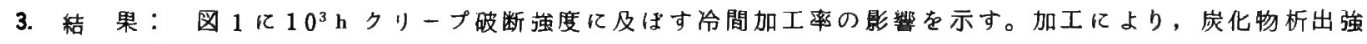

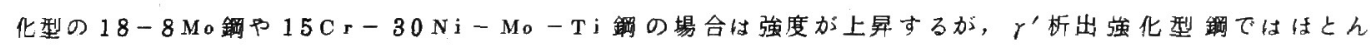
ど変らない。また B 無添加鋼は加工率が $10 \%$ を越えると強度が急激に低下する。B添加鋼の強度は18-8Mo

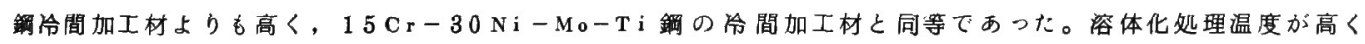

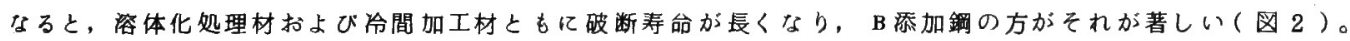
クリープ中, 溶体化処理材では粒内に $r^{\prime}$ 相の微細均一は析出がみられる（写真1）。冷間加工材でも同じよう に午相の均一は析出がみられた。B無添加鋼の $20 \%$ 加工材では再結晶がみられ, この際, 再結晶粒界で掃か れた部分では年相の析出がみられるくるる(写真 2,3)。

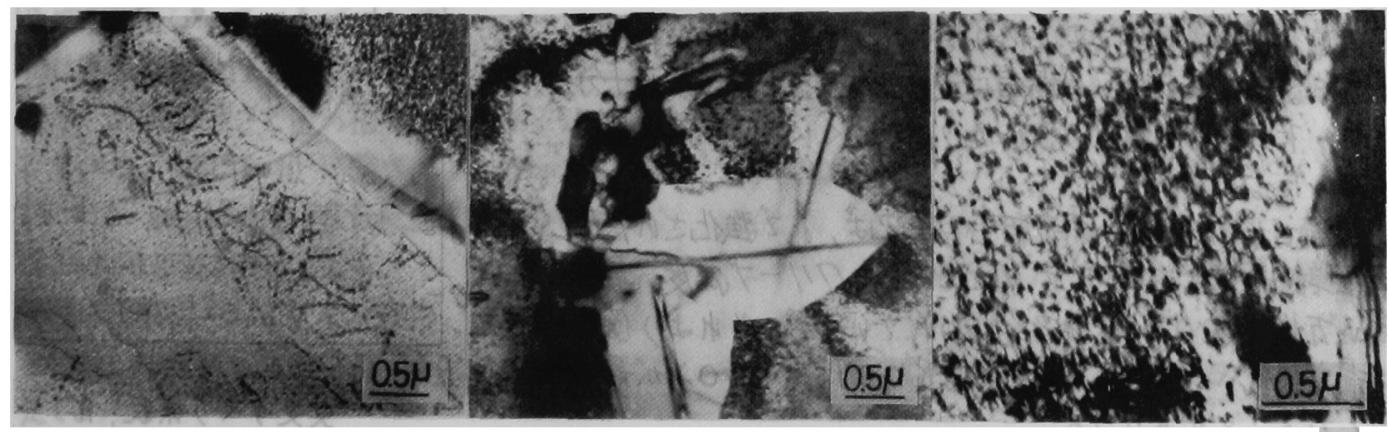

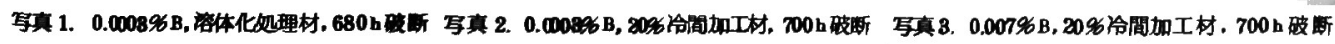


$79-\mathrm{S} 890$

669.14.018.44-172: $620.172 .251 .2: 669.15 \cdot 24 \cdot 26-194.56$

$620.186 .4: 539.379 .4$

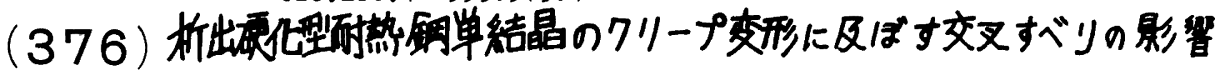

東京都立大学工学部坂大唐晃吉菜正行宫川大海 柬京都立大学大学院 ○松末則道

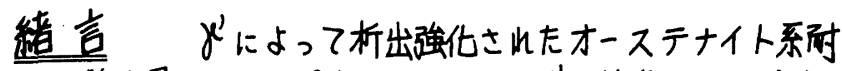

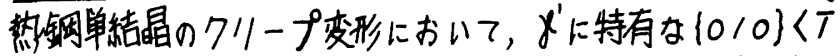
01〉女又すべリがクリープ破朔命命およびクリープ速度に 影著な影響を及ぼすことを明らかにしたので楼告する。

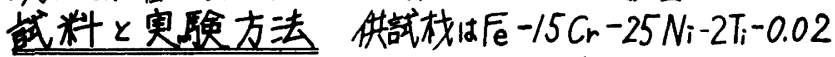

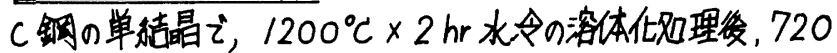

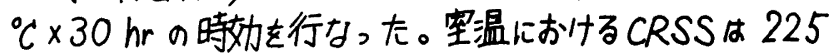

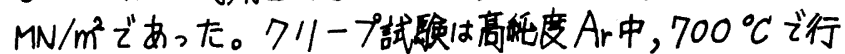
なった。負荷応力は拄すべ系(1/1)〈TO/〉に对する

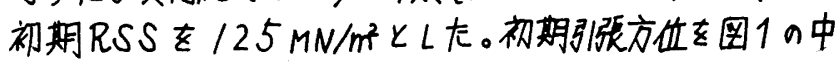
に示す。

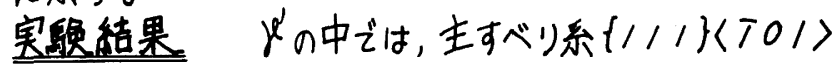
に属するら世ん坛他がすべリ方向を共有する亿010\}面上下

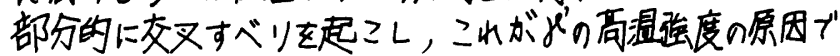
ある女推定されている。部分的に?ロ交叉すべりを起てした

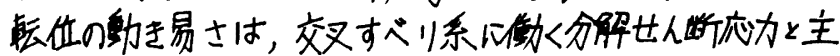
すべリ系に俳く分解世人断応力上の比によ，て定わら川ると 推定し，郊ず係数にを次式で定義する。

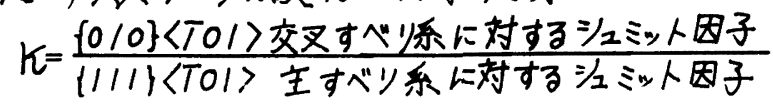

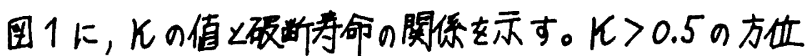
认は破断命命は十分長办ったが，にが0.3から01近ブくに

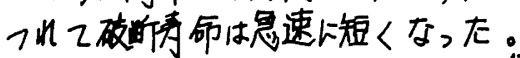

この尼金のクリープ夜形には前帮へで述べたなに，第正

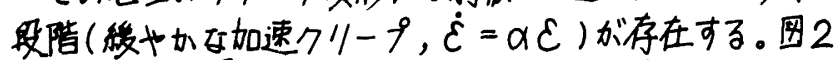

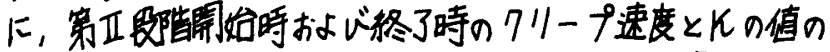
闵拣を示す。K>0.5の埸合は?ルらの7リー7速度は十分

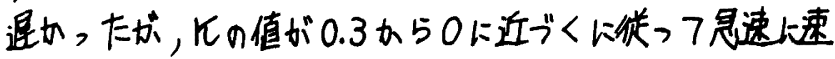
〈なった。

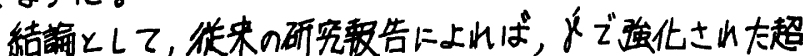

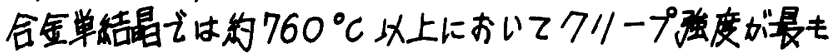

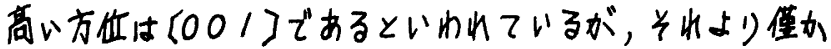

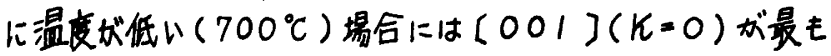
弱くなることがありうる。

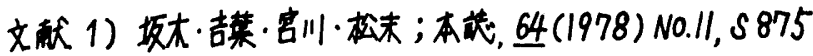

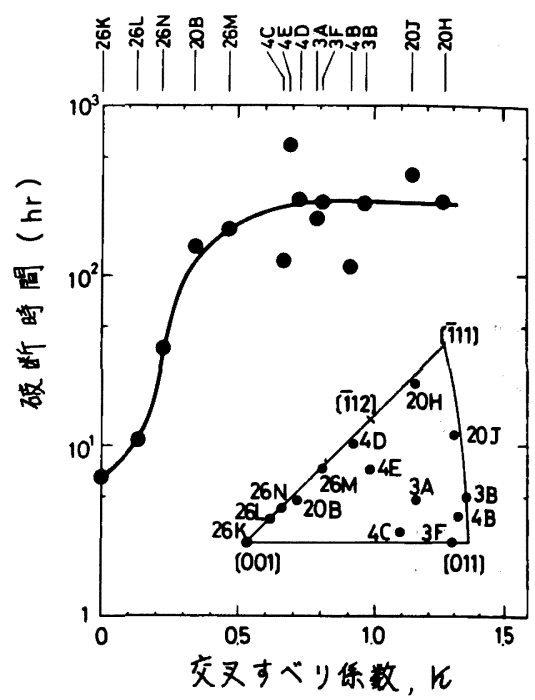

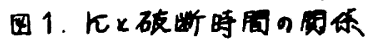

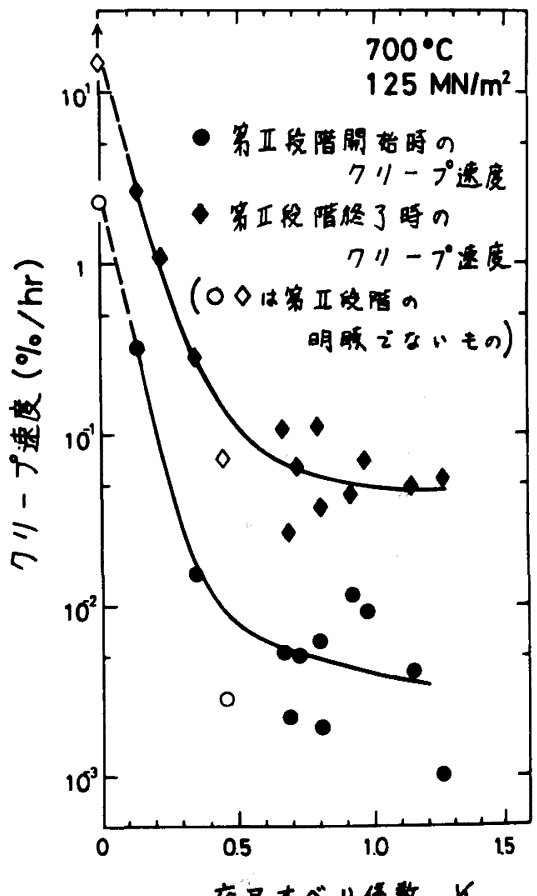

四2.にとフリープ速度の肉系 


\section{(377) SCH22-CF(HK40)のフリリー7破断強さの要因解析}

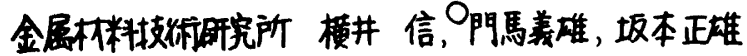 永井移难，吉田吉栄}

1. 楮言 25Cr-20Ni-0.4C鋼(HK40)遗鋳管14チャージについて䄪5万時間までのクリープ破断 データおよびその整理結果をNRIMクリープデータシートNo.16Aとして、来春、発刊の予定である。 本報は二の破断データのチャージ間にみられるバラツキの要因解析を試みたものである。

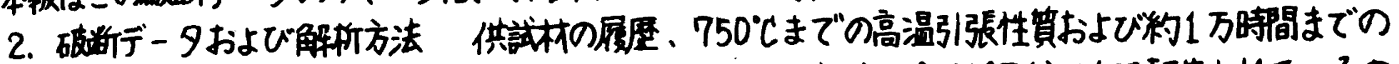
破断デー多につては、すでにNRIM クリープデータシートNo.16 (1974)として報告されているの で省略する。約1万時間を超える破断データと温度バラメータ法による評洒についは、今春、報告し た!。产の結果Larson-Miller (LM) およびManson-Succop (MS) パラメータによよる整理がニの銅㮔 に適当であることボ明らかとなった。罒1はすべての原始データを一括してMSパラメータにより回帰 した曲楾である。本郝ではャージごとにしMパラメータ法(定数最適化)で整理(て得られた800C

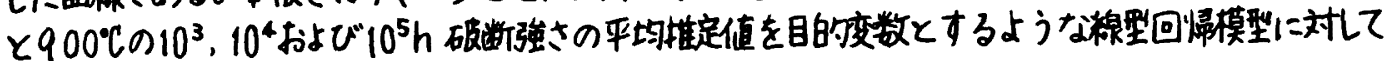
变数選択法を適用した。すなわ5、回婂模型は

$$
Y=b_{0}+b_{1} x_{1}+b_{2} x_{2}+b_{3} x_{3}+\cdots+b_{k} x_{k}+e
$$

ただし、eは媄差で説明变数 $X_{k}$ は $X_{1}=C(\%), \quad X_{2}=S_{i}(\%)$. $X_{3}=M_{n}(\%), \quad X_{4}=\operatorname{Cr}(\%)$. $X_{5}=N_{i}(\%), \quad X_{6}=M_{0}(\%)$.

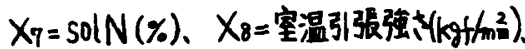
$X_{9}=$ 試醶㬈度での引張強士 $\left(\mathrm{kgt} / \mathrm{m}^{2}\right)$. $X_{10}=X_{Q} 1$ 二対底する伸び $(\%)$ 。 变数避択に士心什る分散比は $F=1.0$ および $F=2.5 を$ 採用した。 3. 結果 表 1は各模型に对して 説明变数を增成士世て最終的心琶択 士れた説明变数番号 $\left(X_{k}\right.$ のK $)$ とY の標草誤差を示している。 全般的にM。量と高温引张强 さが有意となっているが、この 他に高温引張延性も多くの嚗合、 ワリ-フ破断強さと正の相関が

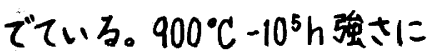
対する solubleN量（交動筑围 は0.03 0.10)(舆味深い。 今後は相織因子および交互作用 去加味した解析を進のて行く予

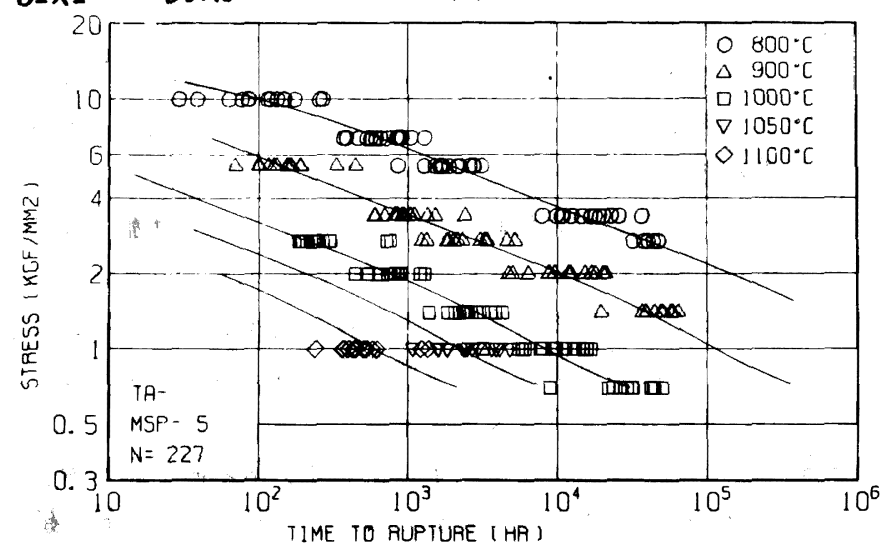

図1.HK40のNRIM 破断デタとMSパラメータ法による回为曲線 （全体を一括，定数影急化，5次）

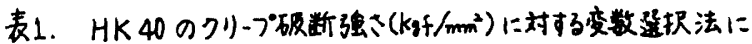

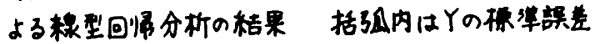

\begin{tabular}{|c|c|c|}
\hline 説明变数 (Y) & $F=1.0$ のと $₹$ & $F=2.50 と ₹$ \\
\hline $800^{\circ} \mathrm{C}-10^{3} h$ 強士 & $10(0.395)$ & 左に同じ \\
\hline $800^{\circ} \mathrm{C}-10^{4} \mathrm{~h}$ 強士 & $1.4(0.130)$ & 左に同じ \\
\hline $800^{\circ} \mathrm{C}-10^{5} \mathrm{~h}$ 强、 & $2,6.9,10(0.202)$ & $6(0.218)$ \\
\hline $900^{\circ} \mathrm{C}-10^{3} \mathrm{~h}$ 強士 & $1.2,3,5,6,8.9,10(0.027)$ & $1.8,9.10(0.056)$ \\
\hline $900^{\circ} \mathrm{C}-10^{4} \mathrm{~h}$ 強 $\mathrm{J}$ & $4,6,7,8,9,10(0.070)$ & $4(0.124)$ \\
\hline $900 \mathrm{c}-10^{5} \mathrm{~h}$ 強士 & $4,6,7,8.9(0.078)$ & 左に同じ \\
\hline
\end{tabular}
定てらる。

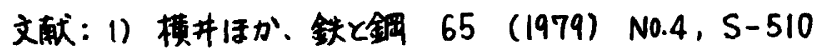


(378) HK40及びNb・Ti添加HK40而㷫遠管の高渴クリープ 变形に伴う静的強度特性の变化について

$$
\begin{aligned}
& \text { 金属阵科技術研究所 ○小泉裕 } \\
& \text { 柬京工䅈大学工学部松尾类田中良平 }
\end{aligned}
$$

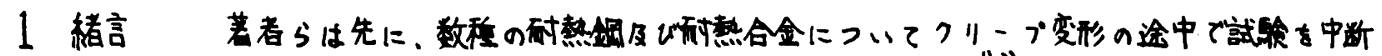

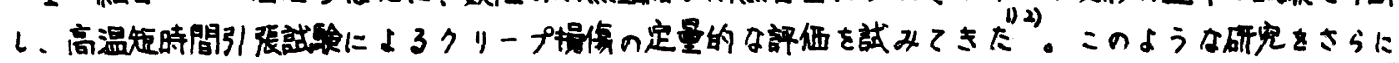

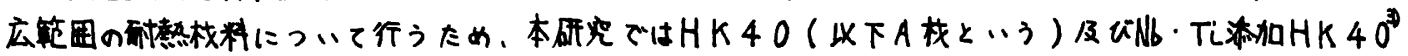

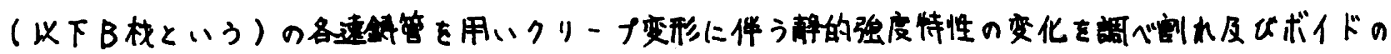
発生成长との成你を模討した。

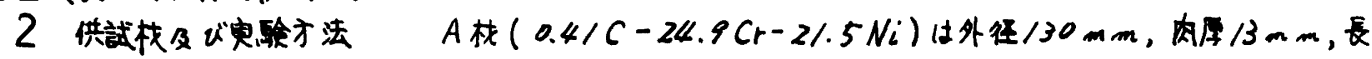

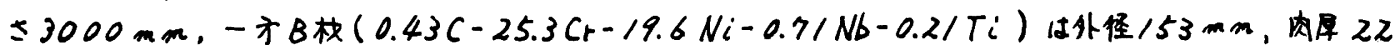

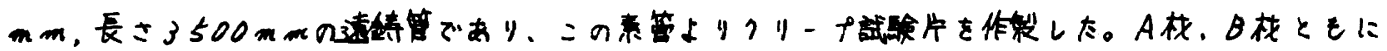

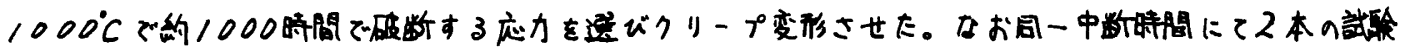

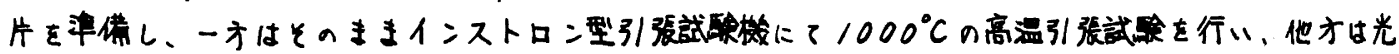

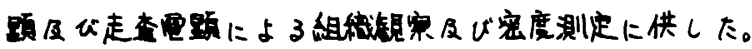

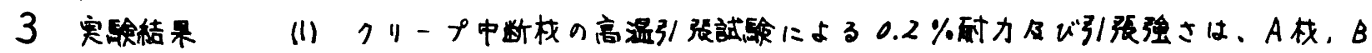

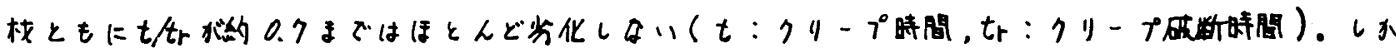

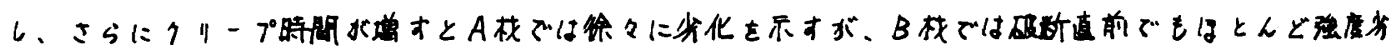

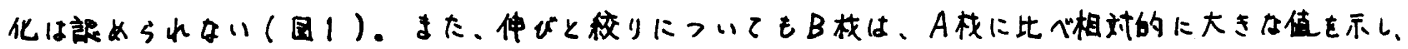
破矿直前ですいさだ $10 \%$ 外上の伸びをす。

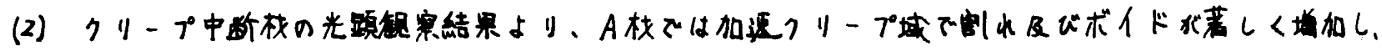
やがて互いに連結粗大化して破断に至る。しかし、B林では表面剂れ及びボイドの数とその大ミミは加

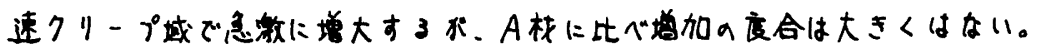

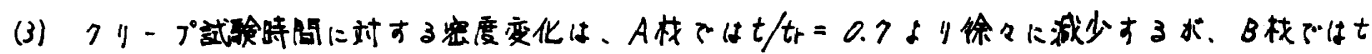
$/ t_{r}=$ 约0.9を超えると大ミく娍少する。

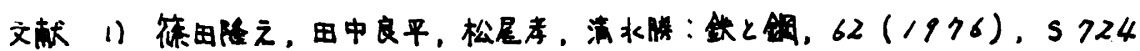

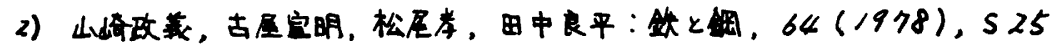

3) T. Shinoda et al : T.ISIJ, 18(1978) p. 139.
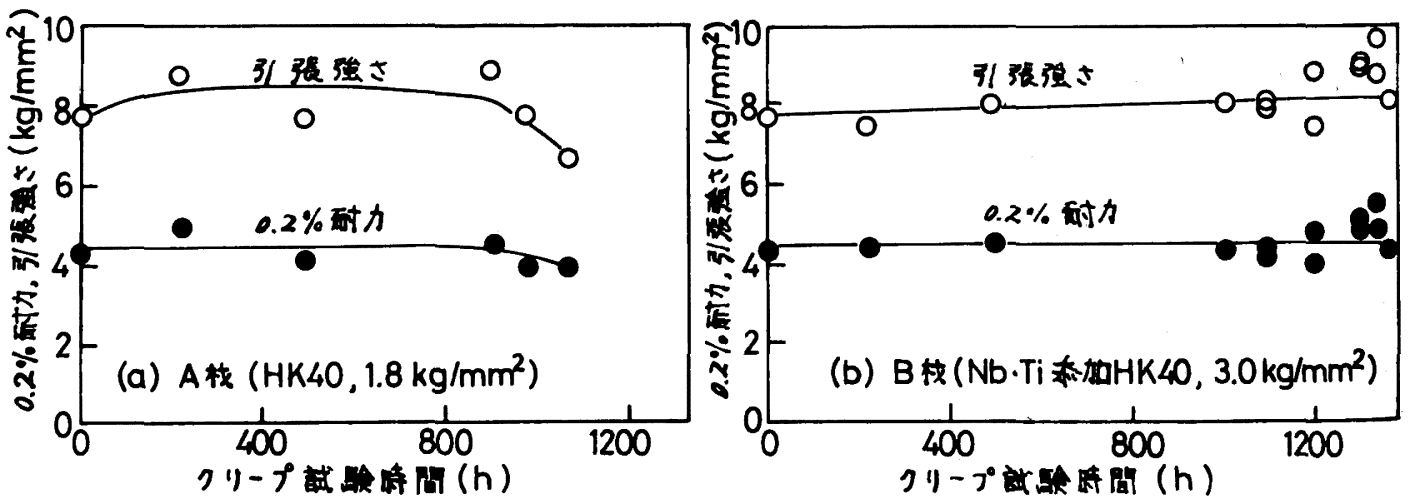

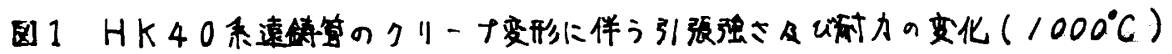


(379) 高Ni遠心鋳造管の耐浸炭性に及ほす各種合金元素の影響

神戸製鋼中央研究可太田定雄小織满

石山勇 $O$ 吉田 勉

\section{1. 緒 言}

エチレン製造用クラッキング・チューブに従来 H K 40 遠心銪造管が用いられているが,しばしば管内面 が著しい浸炭をらけチューブの寿合に大きな影響を及 はしている。既に筆者らは Si,Niが耐德炭生に有効 な元素であり特にSiが著しい効果を示すととを明ら かにしており，また実際のプラントですSi含有重を高 めた HK40がかなり使われている。しかし近年操業条 件の高温化几つれ，さらに耐浸炭制の優れた材料が要 求されるようになってきた。そこで本研究では高 $\mathrm{Ni}$ 遠 心鋳造管について耐浸炭性に及任す $\mathrm{Cr}, \mathrm{Nb}, \mathrm{W}$ 等の合金 元素の影響の俟討を行なった。

\section{2. 試験方法}

$\mathrm{Ni}$ 含有量を $29 \%$ 一定とし Cr含有量を $26 \sim 35 \%$ 変化させたもの，および $25 \mathrm{Cr}-35 \mathrm{Ni}$ 基本成分とし， $\mathrm{Si}, \mathrm{Nb}, \mathrm{Mo}$ ，Wをそれぞれ添加した遠心铸造管尼供試材に 用いた。浸炭試酫はDegusa社製Duferrit KG-6

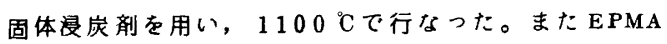
により漫炭C量および表面近併の元素の分布状態を調 ベた。

\section{3. 結 果}

图1亿耐浸炭性に及ばすCr含有量の影幚について示 す。Cr含有重の坦加と共に浸炭深さは减少し, $35 \%$ 以 上では漫炭は認められなくなる。各㮔台金元素の耐浸 炭生に及はす影鄂を図2 亿示す。合金元素を添加した ものは, いずれも $25 \mathrm{Cr}-35 \mathrm{Ni}$ 材に較へ，耐浸炭性は 改善され, 特にWの効果加最当大さく, $\mathrm{Si}, \mathrm{Mo}, \mathrm{Nb} の$ 順になっている。图 3 亿高 $\mathrm{Si}$ 高 $\mathrm{Cr}$ 材の耐浸炭生を $\mathrm{H}$ K 4 0， H P およびそれらの高Si材と比較したものを示 す。H K 40，HP およびそれら高Si材では浸炭が完全 に防止されないのに対し高 Si高 Cr材のものは完全に 防止される。また商 $\mathrm{Si}$ 高 $\mathrm{Cr}$ 材のクリープ破断強度は $\mathrm{H}$ K40より离い強度を示し, 特に延性が著しく優れて いるためエチレン・クラッキング・チューブ用の材料 として有望であると考えられる。

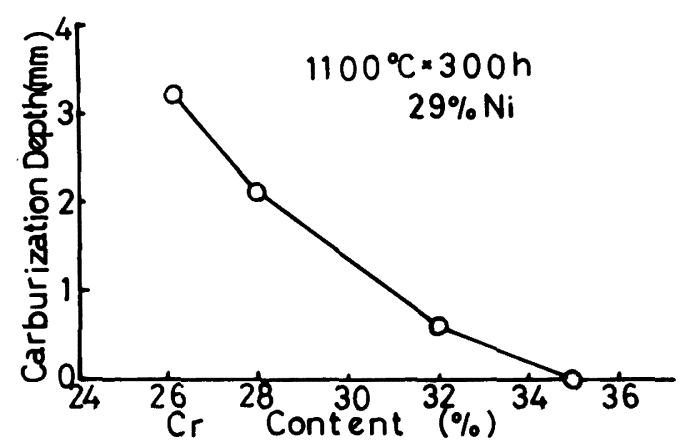

因1. C $r$ 合有卓の影辨

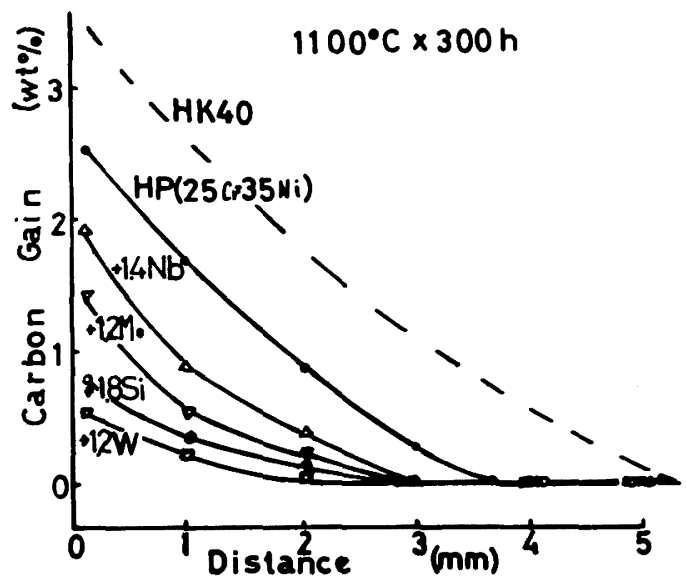

因2. 合金元素の影鄂

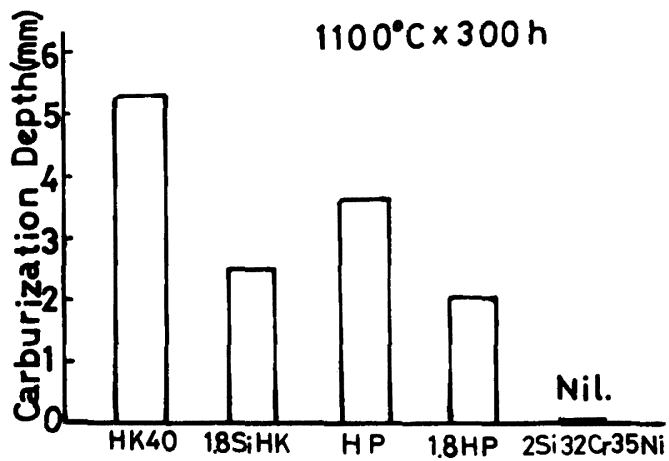

因8. 高 $\mathrm{Si}$ 高 $\mathrm{C} \mathbf{r}$ 材の耐浸炭生 


\section{（380） $\mathrm{Ni}$ 基耐熱合金一Waspaloyの諸特性に及ぼす合金元素の影響}

大同特殊鋼 中央研究所 ○松永健吉 上原紀興

\section{1. 緒 言}

$\mathrm{Ni}$ 基耐熱合金Waspaloy（ $\mathrm{Ni}-20 \mathrm{C} \mathrm{r}-4 \mathrm{Mo}_{\mathrm{N}}-13 \mathrm{Co}-3 \mathrm{~T} \mathrm{i}-1.4 \mathrm{Al}-\mathrm{B}-\mathrm{Z} \mathrm{r}$ ）はガスタービンやジ エットエンジンのディスク,ブレードおよびスペーサー等に使用される。との合金の強度は主として

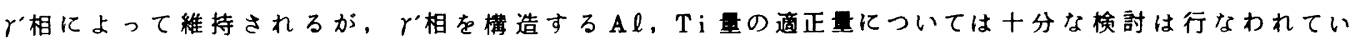
ない。とくに製造性（熱間加工性）と強度に及はす A ， T i 量の影掣は相反する傾向を持つはずであり， この合金の製造技術的な観点からも $\mathrm{Al}, \mathrm{T} \mathrm{i}$ 量の啇正量については検討する必要がある。そとで本報 では, この合金の熱間加工性，常温および高温の機械的性質および時勃硬化性に及はす よび Ti/Al 比の影響について詳細な検討を行なった。

\section{2. 実験方法}

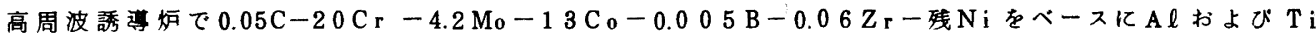
量を变化させた $25 \mathrm{~kg}$ 鉿塊を溶製した。銅塊から直接探取した武験片を用いて高温高速引張試験を行な い熱間加工性を検討した。また，鋼塊を鈠伸して $20 \mathrm{~mm}$ 棒とし，所定の熱処理（1015 C $\times 4 \mathrm{hrW}$. C. ・ $845^{\circ} \mathrm{C} \times 4 \mathrm{hr}$ A.C. $\rightarrow 760^{\circ} \mathrm{C} \times 16 \mathrm{hr}$ A.C. ) を施した後, 常温引張試験, クリープ破断試験（温度；732 ${ }^{\circ} \mathrm{C}$, 応力; $\left.52.7 \mathrm{~kg} / \mathrm{mm}\right)$ および硬さ测定を行ない，機械的性質への影辢を検討した。その他，格子定数 および $\gamma^{\prime}$ 相 $\left\{\mathrm{Ni}_{3}(\mathrm{Al}, \mathrm{Ti})\right\} の$ 体積率への影響についても検討を加えた。

\section{3. 実倹結果}

$\mathrm{A} \ell+\mathrm{T} \mathrm{i}$ 量と熱間加工の可能な温度幅との関俰を図1に示す。 $\mathrm{A} \ell+\mathrm{Ti}$ 量の増加に伴ない加工可能な 温度幅は減少する傾向を示す。 $\mathrm{A} \ell+\mathrm{T} \mathrm{i}$ 量か４.3\%以下の領域で加工可能な温度幅が $2000^{\circ} \mathrm{C}$ 以上となり， 熱間加工性は良好である。 $\mathrm{A} \ell+\mathrm{T} \mathrm{i}$ 量と常温引張性質との関係を因 2 に示す。 $\mathrm{A} \ell+\mathrm{Ti}$ 量の増加に伴ない 引張強さおよび $0.2 \%$ 耐力は增加し，伸びおょび校りは， はとんど変化しない。 $\mathrm{A} \ell+\mathrm{Ti}=4.3 \%$ とし, $\mathrm{T} i / \mathrm{Al}$ 比を 変化させたとさの常温引張性質を図 3 亿示す。 $\mathrm{Al}+\mathrm{l}+\mathrm{T}$ 量を一定にした場合， $\mathrm{Ti} / \mathrm{Al}$ 比の増加に伴ない引張強さお よび $0.2 \%$ 耐力は増加し，伸びおよび校りも若干増加する 傾向を示している。クリープ破断性質には $\mathrm{Al}+\mathrm{T} \mathrm{i}$ 量よ り結晶粒度の影加大であった。また， $\mathrm{Al}$ および $\mathrm{T} \mathrm{i}$ と $\gamma^{\prime}$ 相の析出量および析出形態との関係さらにマトリッ クスの格子定数等についても并せて報告する。

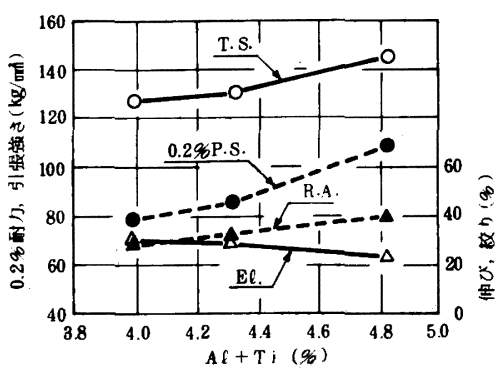

因2. $\mathrm{A} \ell+\mathrm{Ti}$ 常温引張性䆓の関係

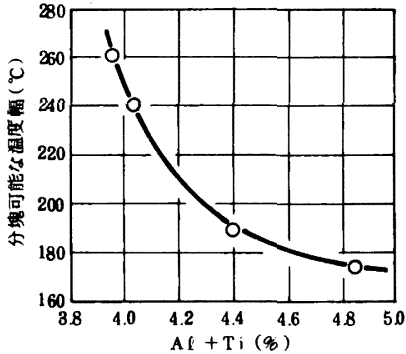

図1. $\mathrm{A} \ell+\mathrm{Ti}$ 量と分塊可能な温度幅との関保

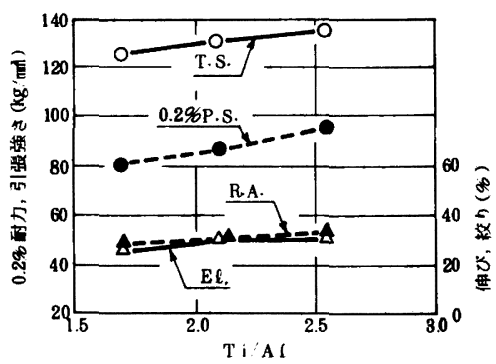

因3. Ti/Al 比と常温引镸性貿の関保 
536.413: 669.1/8: 669.24.018.85

$79-\mathrm{S} 895$

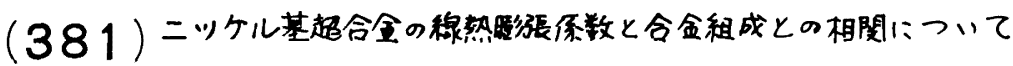

金属材科技许研究所椾克之山崎道夫

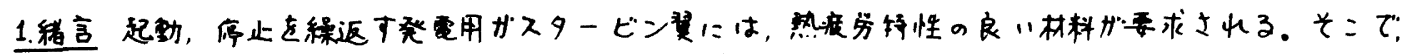

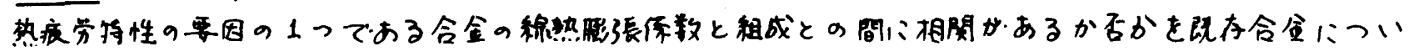
てのデー9をもとに分析，柣討にた。

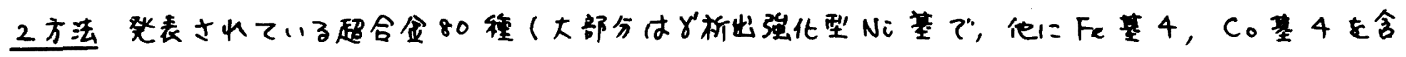

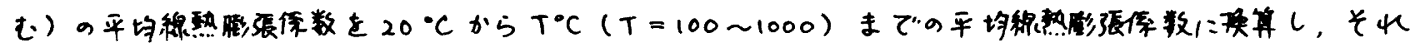

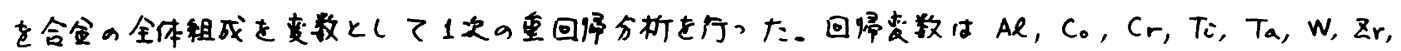

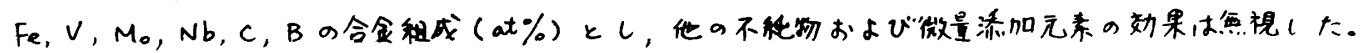

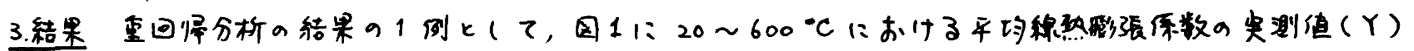

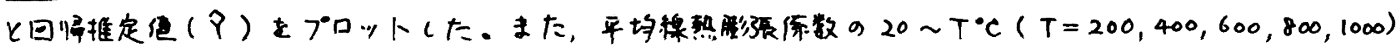

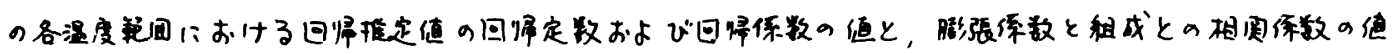

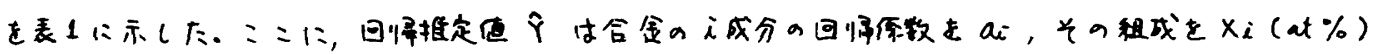

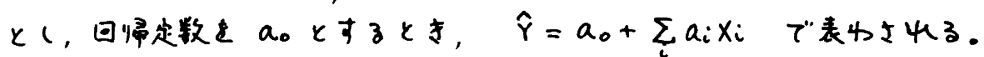

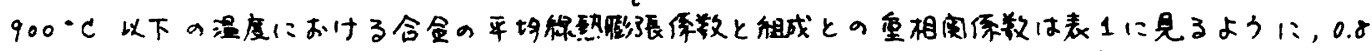

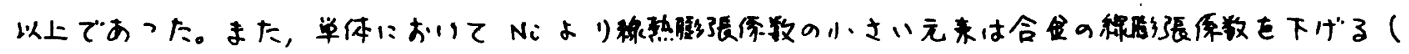

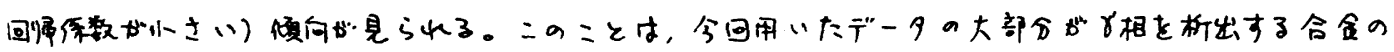

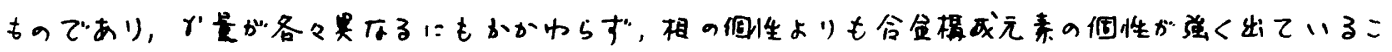

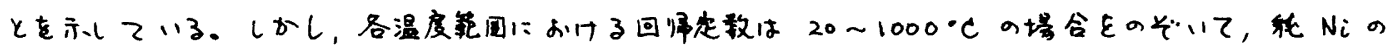

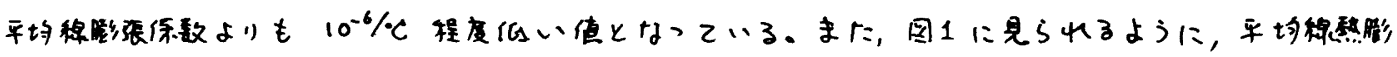

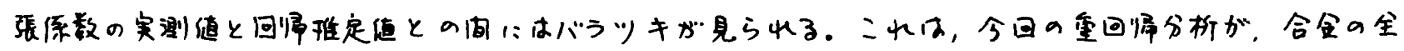

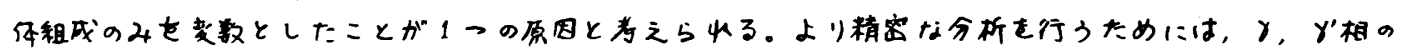

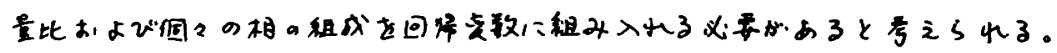

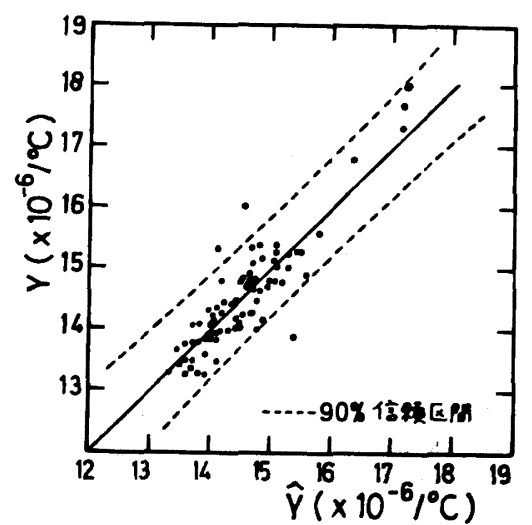

园1. 20 〜 $600^{\circ} \mathrm{C}$ における辛均

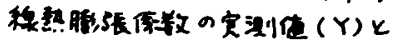

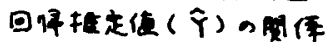

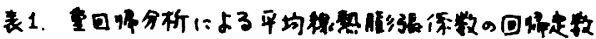

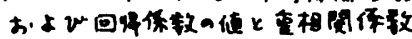

\begin{tabular}{|c|c|c|c|c|c|c|}
\hline \multicolumn{2}{|l|}{ 温度蜼团 } & $200^{\circ} \mathrm{C}$ & $\begin{array}{l}20 \sim \mathrm{C} \\
400^{\circ} \mathrm{C}\end{array}$ & $600^{\circ} \mathrm{C}$ & $800^{\circ} \mathrm{C}$ & $1000^{\circ} \mathrm{C}$ \\
\hline \multicolumn{2}{|c|}{$\begin{array}{c}\text { 回神定政 }\left(a_{0}\right) \\
\left(\times 10^{-6} \% \mathrm{C}\right) \\
\end{array}$} & 12.919 & 14.158 & 14.840 & 15.476 & 16.574 \\
\hline $\begin{array}{c}\text { 回 } \\
\text { 最 } \\
\text { 像 } \\
\text { 数 } \\
\left(a_{L}\right) \\
\left(\times 10^{-6 / p c)}\right)\end{array}$ & $\begin{array}{l}\text { Al } \\
\text { Co } \\
\text { Cr } \\
\text { Ti } \\
\text { Ta } \\
\text { W } \\
\text { Zr } \\
\text { Fe } \\
\text { V } \\
\text { Mo } \\
\text { Nb } \\
\text { C } \\
\text { B }\end{array}$ & $\begin{array}{r}-0.025 \\
0.021 \\
0.006 \\
-0.160 \\
-0.309 \\
-0.199 \\
2.678 \\
0.063 \\
0.167 \\
-0.095 \\
-0.054 \\
-0.167 \\
2.852\end{array}$ & $\begin{array}{r}-0.019 \\
0.015 \\
0.001 \\
-0.198 \\
-0.226 \\
-0.231 \\
0.949 \\
0.054 \\
0.298 \\
-0.130 \\
-0.144 \\
-0.128 \\
1.221\end{array}$ & $\begin{array}{r}-0.012 \\
0.014 \\
0.015 \\
-0.214 \\
-0.257 \\
-0.250 \\
0.521 \\
0.052 \\
0.370 \\
-0.141 \\
-0.162 \\
-0.128 \\
0.466\end{array}$ & $\begin{array}{r}0.000 \\
0.018 \\
0.035 \\
-0.160 \\
-0.333 \\
-0.294 \\
1.067 \\
0.054 \\
0.233 \\
-0.157 \\
-0.116 \\
-0.224 \\
-0.166\end{array}$ & $\begin{array}{r}0.020 \\
0.028 \\
0.052 \\
0.010 \\
-0.384 \\
-0.398 \\
2.263 \\
0.059 \\
-0.266 \\
-0.208 \\
-0.016 \\
-0.423 \\
1.436\end{array}$ \\
\hline \multicolumn{2}{|c|}{ 相㝒质:数 } & 0.847 & 0.881 & 0.877 & 0.842 & 0.716 \\
\hline
\end{tabular}


(382) 高温硫化腐食環境中のNi基耐熱合金の切欠 711 - 破断特性

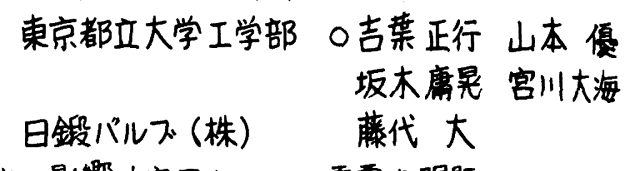

1. 緒 言 耐熱合金のクリーフ。破断強度に対する切欠きの影響は実用上とくに重要な問題のーつであ る。とのため切形状，試駼温度と心力，租織学的因子，材料の延性などの諸因子に着目して種々の研 究が行われているが，環境因子までを考虑に入れた研究はほとんどみられない。著者らは先に，高温硫

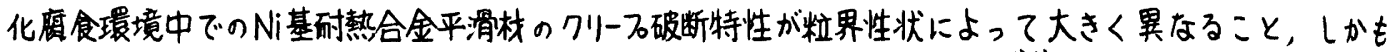
それが主として粒界侵食の進展挙動の相違に起因することを明らかにしだる゙ 本研究では，組䄉学的因 子としての粒界性状と破断延性が大きく異なるNi基耐熱合金の二種颣の熱処理杖について，硫化展食環 境中での切欠ワリーて破断特性を平滑材と比较检討した。

2. 供試杖および实験方法供試杖は前報”と同一組成のInconel 751 である。これに前報で採用した 㷫処理のうち，直線状粒界を有しおもに粒内強度（硬度）を高めるための单純時効（SA）と，粒界の ジグザグ化によって粒界強化を計った直接時効（DA）の二通りの熱边理を施した。試験片は平行部直 径 $7 \mathrm{~mm}$ ，最小断面部遖径 $5 \mathrm{~mm}$ ，切次底半径 $0.5 \mathrm{~mm}$ の $60^{\circ}$ V型環状切次試験片で応力集中係数は2.4 で ある。合成兏は $\mathrm{Na}_{2} \mathrm{SO}_{4} 90 \%+\mathrm{NaCl} 10 \%$ を $40 \mathrm{mg} / \mathrm{cm}^{2}$ の割合で平行部と切欠部に均一に等布し， 200 每の繰返し塗布によって腐食効果を持続させた。試験温度は $800^{\circ} \mathrm{C}$ である。

3. 实験結果 SA材とDA材の応力と破断時間の関係を团1に示す。大气中の破断強度に関しては， SA材はほとんど切強化を示さないが，DA材は顕著な切次強化を示した。これはDA材の破断延性 がSA湘に比べてかなり高いことに起因する゙ろと考えられる。一方，腐食環境中では両㷫処理材とも概し て切次強化の傾向を示すが，切次材における大気中 の破断強度に对寸る腐食環境中の破断強度の此(腐 食破断強度比）で比較すると，との最低值は耐等姏 理材とも平滑材の光れと同程度である。

切次底における粒界侵食形態はSA材とDA材で 異なる。SA材では平滑材の場合と同様に䉼界僈食 の進展速度は速いが，激しい侵食を受ける粒界は比 较的少い。したがって，SA材の破断寿命はおもに 切欠底での優先的な籸界侵食の発生時期に支配され， 兰れに対しては切底における粒界の位置関係が大 きな影䈉を与えるものと考えられる。これに对して， DA材では切㭽部のすべての粒界で侵食が進んで いるが，との進展には一定のクリーフ。時間依存性を示 すため，展食よりも力学的効果の優先する高瓜力短 時閻倒では大気中と同様に切次強化の傾向が著しい。 一方，長時間側では腐食の効果が支配的になるため 平滑材と同程度の強度を示すようになる。

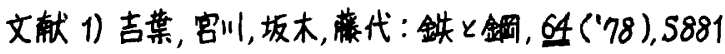
2)
同上
: 同上，吕(79),S22

3）山本，宫川，小林，茷代：同上，杰('77)，1858

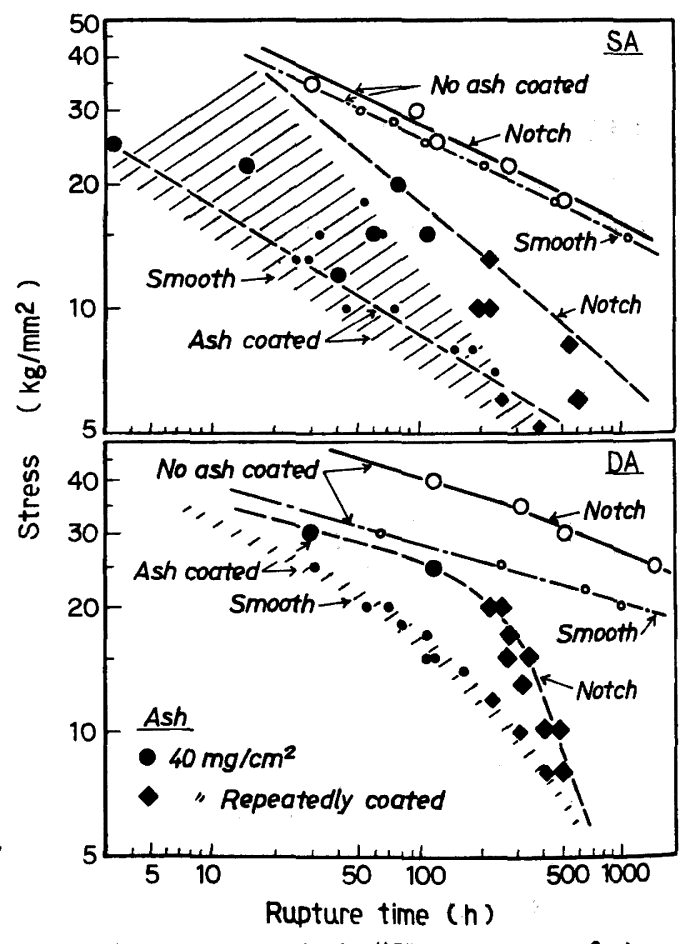

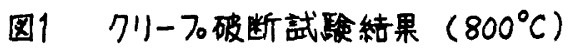

